さ㣗る(ヒミズ 8 頭で464 足). 今日亦での成續から， キタサト，フシ，コウチ，クロシオ，ガーリェピアなざ は，全県下に普通汾布して招り，県南部では，ミタム ラ,ミヤジマ, ダイセン，イカオタマなどが見出され る.な招，松山市内の城山地区では，目下，季䬦的出現 状沿学検甞中であり,さらに, 県下全般にわたつて, 詳 細店調査も続行中である。疫学的に注意する必要のある 種類としては，わずかにフトゲだけであるが，それも， 松山市内からだけ（1956年12月-1957年 3 月の成績）見 出されているにすぎな。（德鳥大・医・病理）

\section{鹿児島地方の恙虫, 特に匢ロイシやカべ種について：} 北原経太・八板宗哉 Kitahara, K. \& Yaita, M. : Tsutsugamushi in Kagoshima District, especially on $D$. okabei

1955 年 3 月より 1956 年 11 月末で鹿児島市内城山雔岩 㥓谷で每月調査定行い, 琉球ネズミ26頭, イエネズミ5 頭，ドブネズミ11頭圭捕隻し珫球ネズミ17頭にドロイシ

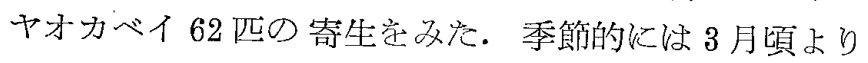
10月頃末で発生し7月頃が最高亡なる様である。宿主は 琉球ネズミ以外から㹥全然認めていない.1956年 8 月, 11月の 2 回に亘り大島郡与論島に渡りドブネズミ32頭, 琉球ネズミ75䫀，ヤマバト 2 羽について検べ琉球ネズミ 7頭にドロイシヤオカベイ10匹の寄生走みたざで他の 種の恙虫は全然認められなかつた。非常に僅かな標本で あつたが与論島の10匹鹿児島の62匹より無作為にとり出 した10匹の標本に基き気候的に，又，地質的に何等かの 変異が久られるのではないかとの予想のもとに比較字試

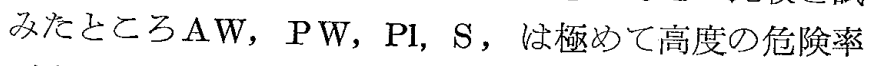
で有意の差を認めた。( $0.1 \%$ \%下)， S B, dsa, ( 1 \%以下), 胴背毛総数, 第II, III列毛数, ( $2 \%$ 以下) であつた。（鹿大・医・公衆衛生）

日本産恙虫の分布に関するその後の知見：田宮猛雄・加 納六郎・熊田信夫 ・金子瑇俊・久鄉準・森川達二 Tamiya, T., Kano, R., Kumada, N., Kaneko, K., Kugoh, T. \& Morikawa, T.: Recent knowledge on the geographical distribution of trombiculid mites in Japan

1954年末に新たに地方性リケッチア症研究班が結成さ れ，日本及び週辺の諸島字対象しして，主として恙虫病 群りケッチア症に関する没学, 㷊介動物, 及び病原体等
の各分野よりの綜合的調查研究が行われて来た. 本研究 の開始以来約 1 ケ年間の記録の中, 各種野生動物（殊に 野而) 及び之等堂宿主さする恙虫の地理的分布, 宿主嗜 好性, 季節的消長, 及び分類形態等に関する中間報告 字, 本学会第 8 回大会（於東大，伝研，1956年 4月） y ツガムシ シンポシウムに於て行つたが, その後も引続 き各種の調查定実施中であり，1956年末迄 2 年余りの期

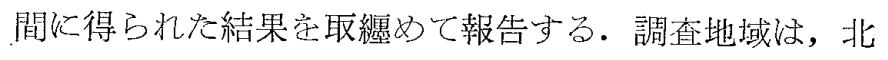
海道, 本州，四国，九州，及び 2,3 の週讱諸島に亘り， 多数の資料が集積されているが，一部の地域定除いては 季飾的消長炇関する充分庆知見定得るに至つていない。

(東京都下大島, 神奈川県三浦半島, 静岡県伊豆半島, 新潟県長岡市の 4 地区に於て行われた季節的消長に関す る調査結果は，別椫報する予定である). 資料こして 取扱つた恙虫幼虫怔， 3 亜科 7 属46種合計106,542 正に 及び，又之等恙虫幼虫の宿主としては，各種獣類14属18 種 2,755 頭及び鳥類18種 69 羽，合計 2.824 個体が算せら れる. 宿主動物及び恙虫の地理的分布, 季節的消長, 種 属特晎性, 及び疫学的考察等比関する詳細尔報告は, 本 研究完結に際して取䌊め詳細《報告の予定であるが，地 理的分布に関する 2,3 知見定記して記録に留め度い. T. (L.) pallida: 北海道南部のエゾキチネズミ, ヒメ ヤチネズミより(1956年6月). T.(L.) orientalis : 長 㥓県対島産のツシマアカネズミより (1956 年 8 月). $T$. (L.) sp. \# 50：秋田県北部産のハタネズミより(1955 年 8 月). $T$. (L.) yasuokai : 鳥取県大山寺産のコウ心゙ モグラより (1956年10月). G. (W.) ogatai : 鳥取県大 山寺産のコウべ注グラより (1956 年 10 月). T. (L.) murotoensis : 愛知県中央部産のアカネズミ, 八タネズ ミより (1956 年 3 月). T. (M.) kochiensis：愛知県中 央部産のアカネズミより (1956年3月). (東京医歯大・ 医動物)

\section{ナガヨツツガムシ群の種とその変異について：佐々学・} 邻室鼻 Sasa, M. \& Iimuro, I.: Studies on the variations in the autumnalis-group of the subgenus Neotrombicula of the Japanese trombiculid mites

ナガヨツツガムシ Trombicula nagayoi は Neotrombicula 亜属の antumnalis 群に属し, この群には日本で T. japonica, T. ichikawaiの 2 種がこの原亦記録され ている. このうち, あとの2 種の幼虫はその形態に変異 がそしいが, nagayoi は東本州から北海道にかけて集め られた標本に胴背毛式户背甲板の大きさの変異がみら れ，こくに基産地の山中のものなごに胴背毛式だけから 